\title{
SOCIOLOGIJA
}

\section{DIDŽIUOJUOSI LIETUVA - LIETUVOS POLITINIO ELITO IR GYVENTOJŲ POŽIŪRIŲ PALYGINIMAS}

Prof. DR. Irmina Matonyté

Generolo Jono Žemaičio Lietuvos karo akademijos Politikos mokslu katedros profesore

Professor at Political Science Department of

General Jonas Žemaitis Military Academy of Lithuania

Šilo g. 5A, LT-10322 Vilnius

irmina.matonyte@lka.lt

Roberta Šiaudvytyté, MA

Generolo Jono Žemaičio Lietuvos karo akademijos

Politikos mokslu katedros specialisté

Specialist at Political Science Department

of General Jonas Žemaitis Military Academy of Lithuania

Šilog. 5A, LT-10322 Vilnius

ro.siaudvyte@gmail.com

\section{Santrauka}

Tautinès tapatybès jausmine raiška nebūtinai kyla iš plačiai įsisqmonintu ir reflektuotu, bet vis dèlto iš daugiau ar mažiau aiškiai atpažistamu kolektyviniu vertybiu, simboliu, istorines atminties akcentu etc. Piliečiu tapatinimasis su tam tikra valstybe ir jos bendruomene neatsiranda "pagal nutylejima", o yra nuolat kuriamas ir tapatybe labai priklauso nuo stipraus ar silpno vienijančio naratyvo, valstybès vardu vykdomos viešosios politikos sprendimu, valstybès situacijos ir 
pasiekimu tarptautineje bendruomeneje ir pan. Straipsnis paremtas tyrimo, kokius Lietuvos - kaip valstybès ir socialinès-kultūrinès visumos (isivaizduojamosios bendruomenès) - bruožus šalies gyventojai bei politinis elitas laiko vertais pasididžiavimo ir pagarbos, rezultatais. Pateikiami ir interpretuojami pagrindiniai Lietuvos politinio elito ir gyventoju požiūrių sutapimai ir skirtumai.

Reikšminiai žodžiai: tautinè tapatybė; valstybė; pilietybė; politinis elitas; viešoji nuomonè.

\section{Ivadas}

Kas galètų paneigti, kad piliečių požiūris ị savo šalị daro didžiulę itaką valstybès gyvenimui, raidai ir bendrai jos gyventojų gerovei. Tą požiūrị formuoja nemažai veiksnių: tapatinimasis su tautine dauguma ar mažuma, nuomonè apie šalies valdymą ir valdžią, tarpasmeninis ir institucinis pasitikejimas, valstybès atstovų kalbų ir veiklos tarptautineje politikos, sporto ir meno arenoje vertinimas ir pan. Tad nieko keisto, kad gyventojų požiūris ị valstybę yra politikos sociologų tyrimų objektas.

Strateginių studijų centras prie Vilniaus universiteto ir Pilietinès visuomenès institutas 2005-2007 metais atliko išsamų tyrimą „Lietuvos tauta: būklè ir raidos perspektyvos"1. Šiuo tyrimu buvo siekiama „identifikuoti svarbiausias Lietuvos visuomenès ir tautos problemas, grèsmes bei kylančius iššūkius ir pateikti galimus šių problemų

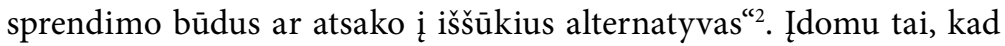
šio tyrimo atspirties taškas - „Lietuvos Tauta, suvokiama kaip Lietuvos visuomenè (Lietuvos piliečiai). Šiuo atveju Lietuvos visuomenè suprantama kaip pilietinè kategorija, t. y. Lietuvos gyventojai, turin-

http://www.civitas.lt/research/lietuvos-tauta-bukles-ir-raidos-perspektyvu-analize/

2 Adomėnas, M.; Augustinaitis, A.; Janeliūnas, T.; Kuolys, D.; Motieka, E. (sud.) Lietuvos tauta: būkle ir raidos perspektyvos. Vilnius: Versus aureus, 2007, p. 12. 
tys pilietines pareigas ir ryšius su valstybe. ${ }^{\text {“3 }}$ Minimoje studijoje pateikiami lyginamieji 1990 m., 1999 m., 2005 m. apklausų duomenys ir, pavyzdžiui, akcentuojama, kad klausimas: „Ar Jūs didžiuojatès, kad esate Lietuvos pilietis?" ilgainiui èmé generuoti vis mažesnị palaikymą, t. y. 1990 m. „labai didžiavosi“ ir „greičiau didžiavosi“ net 88 proc. apklaustųjų, o 1999-aisiais - 59 procentai. ${ }^{4}$ Tačiau taip pat pastebèta, kad Lietuvai įstojus į ES ir NATO (2005 m.) didžiavimosi savo šalimi rodiklis kiek pakilo (iki 66 proc.).

2018 metais išleista A. Ramonaitès, I. Petronytės-Urbonavičienès, P. Skirkevičiaus ir E. Vosyliaus kolektyvinè monografija „Kas eitų ginti Lietuvos? Pilietinio pasipriešinimo prielaidos ir galimybès“, nagrinèjanti Lietuvos gyventojų nuostatas dèl savo valstybès. Ši knyga skirta pilietinio pasipriešinimo galimybèms, kurios siejamos su apklaustųjų požiūriais ị Lietuvą. Tyrimas atliktas $2017 \mathrm{~m}$. vasario-kovo mènesiais. I klausimą: „Ar Jūs didžiuojatès, kad esate Lietuvos pilietis (-è)?“ 30 proc. atsakè, kad „labai didžiuojuosi“, 45 proc. - „greičiau didžiuojuosi“, 15 proc. - „greičiau nesididžiuoju“ ir 4 proc. - „visiškai nesididžiuoju“" Tad matome, kad nors viešajame diskurse dominuoja kritiški šalies ateities perspektyvų vertinimai, per dešimtmetị teigiamo tapatinimosi su Lietuva (didžiavimosi ja) rodiklis pastebimai išaugo ir knygos autoriai tai sieja su Lietuvoje didejjančiu pilietiniu sąmoningumu agresyvios Rusijos politikos akivaizdoje.

Nacionalinès tapatybès ir socialinio identifikavimosi svarba nemąžta ir veikiant globalizacijos procesams. Kiekvienam asmeniui savo kolektyvinès tapatybès suvokimas suteikia tiek vertybinį, tiek savęs, kaip unikalios asmenybès, atradimo ir realizavimo pagrindą. „Priklausomybė tautinei bendrijai užtikrina asmens tęstinumą, sutei-

Ten pat, p. 11.

4 Ten pat, p. 113.

5 Ramonaite, A.; Petronytė-Urbonavičienè, I.; Skirkevičius, P.; Vosylius, E. Kas eitu ginti Lietuvos? Pilietinio pasipriešinimo prielaidos ir galimybès. Vilnius: Aukso žuvys, 2018, p. 81. 
kia prasmę jo egzistencijai, nes brandus žmogus siekia išeiti iš savojo Aš ribų ir susijungti su platesniu Mes kontekstu. ${ }^{\text {"6 }}$ Asmeniui svarbu pačiam save ịvardinti kaip priklausantị tam tikrai bendruomenei, nes tada jis save tarsi apibrèžia ir užkerta kelią kitiems ji apibréžti: „„...> gali būti pasaulyje žinomas ir pagarbiai traktuojamas tik tada, kai pats žinai, kas esi, ir neleidi, kad tavo egzistencijos bei savivokos ribas nustatytų kiti"

Būtent kolektyvinè tapatybė yra veiksmas ir procesas. Būtų gana pretenzinga griežtai nustatyti, kas svarbiau, t. y. ar asmeniui pirmiau reikia išgyventi tam tikrus tapatybès raidos ir raiškos etapus, kad tam tikru metu galètų ịvardinti, kokia jo tapatybè, ar pirmiau pripažįstama sau, kad esu būtent tas, ir tada elgiamasi atitinkamai - taip, kaip turètų elgtis „normalus“ tapatybinès grupès narys. „Tapatybė yra pasiekiama, o ne nustatoma ar pripažįstama - ji yra sąmoninga veikla ir identifikavimasis su tuo, kas mums egzistenciškai svarbu. Nèra ir negali būti nei normatyvinès tapatybès teorijos, nei tapatybès ekspertų, kurie pagal objektyvius kriterijus nustatytų, kas yra kas. ${ }^{\text {“8 }}$ Deja, vis dar „didelei daugumai lietuvių intelektualų priklausymas nacijai yra tas pats, kas priklausymas tautybei. Šis politinių ir kultūrinių terminų supainiojimas pasiekia apogejjų, kai nesugebama - arba sąmoningai nenorima - tapatinti lietuviškumo su Lietuvos pilietybe. Taip išeina, kad jeigu žmogus yra lenkų, rusų arba žydų kilmès, jis negali būti tikras lietuvis. Polinkis įsivaizduoti lietuviškumą griežtai etnokultūrine, o ne politine prasme liudija labai siauras, nelanksčias ir uždaras lojalumo bei tapatybès sampratas, lemiančias lietuvių sąmonès nusistatymą. "9

6 Antinienè, D. Asmens tautinio tapatumo tapsmas. Sociopsichologinès šio proceso interpretacijos. Sociologija. Mintis ir veiksmas. 2002/2, p. 101.

7 Donskis, L. Globalizacija ir tapatybė: asmeninès pastabos apie lietuviškuosius tapatybès diskursus. Sociologija. Mintis ir veiksmas. 2006/2, p. 71.

8 Ten pat, p. 71.

9 Donskis, L. Tapatybe ir laisvė: trys intelektualiniai portretai. Vilnius: Versus aureus, 2005, p. 48-49. 
Sunku prieštarauti minčiai, kad „globalizacijos paveiktame nūdienos pasaulyje, kuriame beveik nebeliko lokalinių civilizacijų ir tradicinès socialinès sanklodos, tapatybė nustojo buvusi priskyrimo ir paveldejimo dalyku. Tapatybę tokiame pasaulyje mes sąmoningai pasirenkame. ${ }^{\text {10 }}$ Ir kartais prireikia stiprios valios jai išlaikyti. „Tapatybè yra kupinas ịtampų savęs ir mus supančio pasaulio interpretacijos ir supratimo laukas, kuriame kryžiuojasi tai, ką apie mus galvoja ir sako kiti, ką apie save galvojame ir kalbame patys, ir kuo mes patys norime būti. <...> Tapatybè yra visų pirma sąmoninga veikla, o ne vien jausena. "11 „Realiame pasaulyje tapatybè visada reiškia žmonių tapatinimąsi su kolektyvinès atminties, sentimento ir vaizduotès struktūromis."12

Lietuvoje (2018 m.) vykstančių intensyvių politinių ir pilietinių ginčų dèl dvigubos pilietybès šviesoje ịdomu gilintis ị tai, kuriuos Lietuvos - kaip valstybės ir socialinės-kultūrinès visumos (ịsivaizduojamosios bendruomenès ${ }^{13}$ ) - bruožus dabartiniai faktiniai Lietuvos gyventojai laiko vertais pasididžiavimo ir pagarbos. Tokio teigiamo vertybinio tapatinimosi su savo šalimi aspektai yra šiuolaikinių politinès kultūros tyrimų dalis, nes tiek socialinès srities mokslininkai, tiek demokratijos principus gerbiantys politikai vis plačiau pripažista keletą dalykų.

Pirma, tautinės tapatybės jausminè raiška kyla nebūtinai iš plačiai issisąmonintų ir reflektuotų, bet vis dèlto iš daugiau ar mažiau aiškiai atpažįstamų kolektyvinių vertybių, simbolių, istorinės atminties akcentų ir pan. Antra, bet kuriuo atveju - net ir „automatinio“, vadinamojo nuliniais reikalavimais pagrịsto pilietybès igijimo atveju - tapatinimasis su tam tikra valstybe ir jos bendruomene neatsiranda „pagal nutyleji-

${ }^{10}$ Donskis, L. Globalizacija ir tapatybė: asmeninès pastabos apie lietuviškuosius tapatybès diskursus. Sociologija. Mintis ir veiksmas. 2006/2, p. 70-71.

11 Ten pat, p. 71.

12 Donskis, L. Nacionalizmas ir globalizacija: XXI amžiaus iššūkiai Lietuvai. Kultūros barai. 2002/10 (455), p. 10.

13 Anderson, B. Isivaizduojamos bendruomenès. Apmastymai apie nacionalizmo kilme ir plitima. Vilnius: Baltos lankos, 1999, p. 20-23. 
mą", o yra nuolat kuriamas, persvarstomas, patiriamas, t. y. kultivuojamas, o kolektyvinè tapatybė labai priklauso nuo stipraus ar silpno vienijančio naratyvo, valstybės vardu vykdomos viešosios politikos sprendimų, valstybės situacijos ir pasiekimų tarptautinèje bendruomenejje ir pan. Kaip teigia A. Giddensas, „refleksyvinis Aš projektas, kuris verčia palaikyti rišlius, bet nuolatos revizuojamus biografijos naratyvus, yra igyvendinamas perfiltruotų per abstrakčias sistemas daugiariopų pasirinkimų kontekste“"14. Be to, „globalizacijos eroje tapatybè yra daugiamatė ir apima bent keletą tarpusavyje susisiejančių ir komunikuojančių socialinès bei kultūrinès patirties sluoksnių “15. Visais šiais aspektais net ir to paties asmens didžiavimosi savo šalimi akcentai gali kisti keičiantis gyvenimui, kaupiant ir vertinant savąją patirtį, sava laikomos valstybès istoriją, jos raidą ir perspektyvas, valstybei atstovaujančių asmenų veiklą, pasiekimus ir taip toliau.

Ryškesni tapatybių skirtumai tikètini tarp atskirų socialinių grupių atstovų, besiskiriančių išsilavinimu, amžiumi, etnine kilme, gyvenamąja vieta (įskaitant ir savo bei artimųjų emigracijos patirtis) etc. Vis dèlto daugiausia demesio demokratinèje visuomenejje turètų sulaukti galimi neatitikimai tarp to, kuo (čia, Lietuvoje) didžiuojasi šalies gyventojai (visuomenès nuomonè), ir kuo - jos politinis elitas (pagrindiniai teisètų sprendimų prièmejjai ir atstovaujamosios demokratijos lyderiai).

\section{Tyrimo metodika}

Šiame straipsnyje (kuris paremtas politinio elito ir Lietuvos gyventojų tyrimu) bus siekiama išsiaiškinti, ar (kaip) skiriasi politinio elito ir visuomenès nuomonès ir požiūriai ị Lietuvos, kaip valstybės ir kaip socialinès visumos, bruožus, ar politinis elitas labiau negu ben-

${ }^{14}$ Giddens, A. Modernybe ir asmens tapatumas. Vilnius: Pradai, 2000, p. 14.

15 Donskis, L. Globalizacija ir tapatybė: asmeninès pastabos apie lietuviškuosius tapatybès diskursus. Sociologija. Mintis ir veiksmas. 2006/2, p. 82. 
drai visi šalies gyventojai didžiuojasi būdami Lietuvos piliečiai ir turèdami Lietuvos Respublikos pasus (su kuriais, beje, be vizos galima keliauti ị 119 valstybių; palyginkime - „galingiausias“ šiuo atžvilgiu Singapūro Respublikos pasas garantuoja bevizes keliones ị 127 šalis $^{16}$ ).

Empirinè medžiaga imama iš dviejų apklausų, parengtų Tarptautinès socialinių tyrimų programos (ISSP) klausimyno pagrindu. Klausimyne kartojosi dvi klausimų serijos:

Pirmas klausimas (žr. Priedai, 1 lentelè) - „Ar jūs didžiuojatès Lietuva dèl...?“: „...to, kaip joje veikia demokratija; jos politinès ịtakos pasaulyje; jos ekonominių pasiekimų; jos socialinės apsaugos sistemos; jos mokslinių ir technologinių pasiekimų; jos pasiekimų sporte; jos pasiekimų mene ir literatūroje; jos karinių pajėgų; jos istorijos; to, kad su visomis visuomenès grupèmis joje elgiamasi vienodai ir teisingai.“ Buvo pateikti 4 galimų atsakymų variantai: „Labai didžiuojuosi“; „Šiek tiek didžiuojuosi“; „Nelabai didžiuojuosi“; „Visai nesididžiuoju.“

Antras klausimas (žr. Priedai, 2 lentelè) - „Pritariate ar nepritariate toliau nurodytiems teiginiams?“: „Man geriau būti Lietuvos piliečiu nei bet kurios kitos pasaulio šalies piliečiu“; „Šiuo metu Lietuvoje yra tam tikrų dalykų, dèl kurių man gèda“; „Pasaulis būtų geresnis, jeigu žmonès iš kitų šalių būtų panašesni ị lietuvius“; „Apskritai Lietuva yra geresnè šalis nei dauguma kitų šalių“; „Žmonès turi palaikyti savo šalị, net jei ji eina neteisingu keliu“; „Kai mano šaliai pasiseka tarptautinèse sporto varžybose, aš didžiuojuosi tuo, kad esu lietuvis“; „Aš dažnai nesididžiuoju Lietuva tiek, kiek noréčiau“; „Pasaulis būtų geresnis, jei lietuviai pripažintų Lietuvos trūkumus.“ Buvo pateikti 5 galimų atsakymų variantai: „Labai pritariu“; „Pritariu“; „Nei pritariu, nei nepritariu“; „Nepritariu“; „Labai nepritariu“.

Pagal atsakymų ì šias dvi klausimų serijas pasiskirstymą toliau pranešime tarpusavyje lyginamos dvi populiacijos - Lietuvos gy-

${ }^{16}$ Global Passport Power Rank 2018, <https://www.passportindex.org/byRank.php > 
ventojai ir Lietuvos parlamentarai (nacionalinis politinis elitas). Reprezentatyvi šalies gyventojų apklausa $(\mathrm{N}=1194)$ buvo atlikta 2013 metais minètos Tarptautinès socialinių tyrimų programos (ISSP) užsakymu ir atitiko reprezentatyvios apklausos standartus pagal lyties, amžiaus, gyvenamosios vietos ir išsilavinimo kriterijus. O Lietuvos Seimo narių apklausa vyko $2017 \mathrm{~m}$. kovo-gegužès mėnesiais. Seimo narių apklausa reprezentatyvi tiek Seime atstovaujamų partijų, tiek Seimo narių politinès patirties ir lyties atžvilgiu (žr. Priedai, 3 ir 4 lentelès). Tarp šių dviejų apklausų esantis laiko skirtumas, aišku, moksliniam analizès tikslumui nepadeda, tačiau žinant, kad tapatinimasis ir vertybinio pobūdžio nuomonès bei jausenos nèra labai labilios, greit kintančios ar „švytuojančios“, dviejų apklausų rezultatų palyginimas yra pakankamai pateisinamas ir pagrịstas.

\section{Tyrimo rezultatai}

Lyginamoji analizè rodo bendrą tendenciją: Lietuvos politinis elitas yra labiau linkęs akcentuoti (atsakyti „visiškai pritariu“) savo šalies pasiekimus, vertus pasididžiavimo, o Lietuvos gyventojų nuostatos dèl visų minimų ir galimai pasididžiavimo vertų sričių yra gerokai nuosaikesnès (atsako „pritariu“) (žr. Priedai, 1 diagrama). Tarp elitą ir gyventojus vienijančių motyvų, labiausiai skatinančių didžiuotis Lietuva, yra Lietuvos pasiekimai sporto srityje, Lietuvos istorija ir Lietuvos pasiekimai meno ir literatūros srityse. Absoliuti dauguma politinio elito (daugiau negu 90 proc.) ir keturi iš penkių šalies gyventojų (daugiau negu 80 proc.) „visiškai pritaria“ ar „pritaria“, kad sportas, istorija ir menai yra Lietuvos stiprybės ir garbès šaltiniai. Panaši tendencija, nors kiek mažesnio masto, yra ir didelis politinio elito ir gyventojų didžiavimasis Lietuvos mokslo ir technologiju pasiekimais.

Tačiau yra ir vienas neigiamas motyvas, dèl kurio politinio elito ir gyventojų nuomonès sutampa, - tai neigiamai vertinama šalies socia- 
linès apsaugos sistema: vos penktadalis Seimo narių ir panaši proporcija šalies gyventojų teigè, kad Lietuvoje veikianti socialinės apsaugos sistema yra verta pagarbos. Tokiu atveju tikriausiai akivaizdu, kad šių retų teigiamai Lietuvos socialinès apsaugos sistemą vertinančių respondentų „referentiné grupe“, su kuria mintyse respondentai lygino Lietuvą, buvo ne iš ES valstybės narès ir ne iš EBPO valstybès narès. „Referentinès grupès“ šalys greičiausiai priklausė buvusiai Sovietų Sąjungai.

Didžiausias politinio elito ir gyventojų nuomonių išsiskyrimas pastebimas srityse, susijusiose su viešuoju valdymu („to, kad su visomis visuomenès grupèmis joje elgiamasi vienodai ir teisingai“), demokratija („to, kaip joje veikia demokratija“) ir ekonomika („jos ekonominių pasiekimų“). Čia gyventojų vertinimai yra labai žemi, o politinio elito (savo veiklos) vertinimai yra gana aukšti. Gal dèl to būtų galima kaltinti politinio elito savikritikos trūkumą? Kita vertus, nieko keisto, kad viešojo valdymo paveikslą valdantieji ir Lietuvos gyventojai mato iš visiškai skirtingų perspektyvų.

Smarkiai skiriasi ir politinio elito (didelis) bei gyventojų (menkas) didžiavimasis Lietuva dèl jos politinès įtakos pasaulyje: politikai akivaizdžiai tuo labai didžiuojasi (86 proc. atsakè teigiamai), tačiau tik 24 proc. gyventojų reiškia panašias teigiamas nuostatas. Čia, kitaip negu visų kitų apklausoje vertintų motyvų atveju, abi lyginamos grupès (elitas ir gyventojai) tikriausiai rèmėsi iš esmès skirtingomis atskaitos sistemomis: politikai žiūrejjo iš plačios laiko, istorijos, ịvairiapusès itakos sampratos ir daugiapolès tarptautinių santykių perspektyvos, o gyventojai - iš siauresnių realistinių pozicijų. Tokią interpretaciją patvirtina ir nemažas skirtumas (nors, tiesa, jis yra gerokai mažesnis nei vertinant tarptautinę politinę įtaką) tarp to, kaip politinis elitas ir gyventojai vertina Lietuvos karines pajègas. Beje, gyventojų didžiavimasis (siekęs 50 proc.) Lietuvos karinèmis pajègomis $2013 \mathrm{~m}$., kai buvo stipriai taupoma krašto apsaugos biudžeto sąskaita, yra tiesiog fenomenalus ir vertas tolesnio tyrimo, ypač turint galvoje, kad šian- 
dieninejje Lietuvoje viešoji politika šioje srityje stipriai pakitusi. Politinio elito pasididžiavimas Lietuvos karinèmis pajègomis siekẻ 86 proc. (2017 m.). Labiausiai ambivalentiškai ir prieštaringai savose grupèse politinis elitas ir gyventojai vertina tai, ar su visomis visuomenès grupèmis joje elgiamasi vienodai ir teisingai. Lietuvos politikai yra linkę šiek tiek labiau (56 proc.) tam pritarti, o šalies gyventojai tam pritaria šiek tiek mažiau (39 proc.). Taigi, nors ir mažesniu mastu negu vertinant socialinès apsaugos sistemą, ir politikai, ir gyventojai pripažįsta, kad socialinio teisingumo, nediskriminavimo ir žmogaus teisių principai nèra gerai ịtvirtinti ir reikalauja daugiau politinès ir pilietinès valios pastangų.

„Emocingiausioje“ ir jausmingiausioje klausimų serijoje, kur buvo tiesiogiai klausiama apie gèdos ir pasididžiavimo, teigiamo ir neigiamo išskirtinumo jausmus, išgyvenamus dèl tapatinimosi su Lietuva (buvimo Lietuvos piliečiu), abiejų grupių respondentų atsakymai labiau varijuoja (žr. Priedai, 2 diagrama). Vis dèlto politinio elito ir gyventojų nuostatos iš esmès sutampa vertinant tiek labiausiai skatinančius didžiuotis savo šalimi, tiek ir didžiausią gèdą keliančius dalykus. Atitinkamai pasididžiavimą dèl sporto pasiekimų reišké 84 proc. politinio elito ir 78 proc. gyventojų, o nusivylimą dẻl Lietuvoje esančių dalykų, t. y. „dèl kurių man gėda“, reiškẻ 73 proc. politinio elito ir 66 proc. gyventojų.

Nacionalinio išskirtinumo (mesianizmo) rodikliai abiejose lyginamose grupėse yra santykinai maži: tik 4 proc. Lietuvos elito ir 17 proc. gyventojų mano, kad pasaulis būtų geresnis, jei kitų šalių žmonès būtų panašūs ị lietuvius. Nors, kita vertus, galbūt XXI amžiuje yra sumažėjęs tam tikrų savybių priskyrimas tautoms - ko gero, tam ịtakos gali turèti globalizacijos pasekmès: pasaulis atviras kiekvienam ir naivus tautinių savybių skirstymas gali būti būdingas nebent konservatyviems provincijos gyventojams. Savo valstybę gyventojai vertina kritiškiau negu elitas - 47 proc. (palyginti su 30 proc. politinio elito) teigè, kad lietuviams būtų pravartu pripažinti Lietuvos trūkumus. Po- 
litinio elito nuostatos išsiskyrè vertinant pilietybę - net 91 proc. teigè, kad jiems tikrai daug geriau būti Lietuvos, o ne kurios kitos šalies piliečiu. O Lietuvos pilietybės privalumus ir teigiamą išskirtinumą patvirtino tik 56 proc. šalies gyventojų.

Nedidelé politinio elito dalis (26 proc.) ir dar mažesnè dalis gyventojų (21 proc.) teigé, kad apskritai Lietuva yra geresnè šalis nei dauguma kitų šalių. Didesnis atotrūkis yra ir tarp politinio elito bei gyventojų atsakymų ị teiginị, kad „dažnai nesididžiuoju Lietuva tiek, kiek noréčiau“ (32 proc. elito ir 48 proc. gyventoju)).

İdomu ir tai, kad šioje serijoje duomenų, kurie atskleidžia būtent jausminiais pagrindais formuojamą ir reiškiamą santykị su Lietuva, politinio elito vertinimai nebūtinai visose kategorijose buvo pozityvesni negu paprastų gyventojų (ką parodè aptartas pjūvis, paremtas objektyvesniais vertinimo kriterijais). Pavyzdžiui, kaip jau minèta anksčiau, tai, kad „šiuo metu Lietuvoje yra tam tikrų dalykų, dèl kurių man gèda“, pripažįsta 73 proc. politinio elito atstovų (palyginti su šiek tiek žemesne 66 proc. gyventojų proporcija). Seimo nariai panašiai, bet šiek tiek labiau negu gyventojai yra linkę pritarti ir nuostatai, kad „žmonès turi palaikyti savo šalị, net jei ji eina neteisingu keliu“: abiejose lyginamose grupèse šiai nuostatai pritaria mažiau negu pusé apklaustųjų (atitinkamai 45 proc. ir 43 proc.). Tačiau tokia Seimo narių nuostata yra pavojingai priartejusi prie 50 procentų. Šiame straipsnyje dèl santykinai mažo kai kurių partijų apklaustų atstovų Seime skaičiaus susilaikysime nuo tolesnès analizės, koks yra Seime atstovaujamų partijų respondentų polinkis pritarti stiprios politinės valios diktatui.

Jausminių nuostatų, susijusių su Lietuva, apžvalgą, kurioje lyginame politinio elito ir visuomenès nuomonès pozicijas, galime baigti dar vienu sporto akcentu: „kai mano šaliai pasiseka tarptautinėse sporto varžybose, aš didžiuojuosi tuo, kad esu lietuvis“. Taip teigè absoliuti abiejų grupių respondentų dauguma (atitinkamai 86 proc. ir 78 proc.). 


\section{Apibendrinimas}

Apibendrinant šiuos du empirinių duomenų blokus, galima daryti keletą išvadų. Pirma, kalbant apie tapatinimąsi su Lietuva, matyti, kad politinis elitas ir gyventojai vis dèlto negyvena atskiruose „burbuluose“, jų požiūriai ir jausenos, susijusios su Lietuva (Lietuva kaip valstybe, kaip socialine-kultūrine visuma, kaip tarptautinių santykių pasaulio dalimi ir pan.), tarpusavyje nemažai sutampa. Lietuvos politinị elitą ir gyventojus tikrai vienija sporto pergalès. Tačiau pastebima ir reikšmingų neatitikimų tarp Lietuvos politinio elito bei gyventojų vertinimų. Ryškiausi jie yra demokratijos kokybės, socialinio teisingumo srityse ir svarstymuose apie Lietuvos vietą plačiajame pasaulyje. Politinio elito atstovai - taip, kaip ir prognozuoja klasikinès socialinio statuso teorijos, - dèl aukštesnio išsilavinimo, stipresnių pozicijų galios struktūroje, didesnių pajamų ir pan. Lietuvoje mato daugiau šviesių spalvų, negu jų galima išvysti analizuojant bendrą visuomenès nuomonę.

Antra, vertinant tiek pagal platoniškąją valdovo sampratą, tiek pagal demokratinio elitizmo principus, politinis elitas - lyginant ji su paprastais piliečiais - turètų jaustis labiau atsakingas už savo šalị, už savo veiksmus, išgyventi stipresnius gèdos už jos nesėkmes ir pasididžiavimo dèl jos pasiekimų jausmus, jie turètų būti stipresni negu gyventojų. Tačiau Lietuvos atveju tai būtų galima pritaikyti tik iš dalies. Vertinant teigiamus mūsų šalies aspektus dažniausiai atsakymas yra „taip“ - politinis elitas nesivaržydamas reiškia savo pritarimą ir palaikymą. O vertinant neigiamus Lietuvos aspektus vis dèlto atsakymai linksta „ne“ link, politinio elito atsakymuose sunku aptikti labai stiprių politinės moralès ir politinès atsakomybès principų.

Trečia, kaip jau minèta, gyventojų nuomonès apklausa pagal aptariamus klausimus yra atlikta 2013 metais. Būtų ìdomu vèl atlikti panašią apklausą ir patikrinti bent du dalykus. Pirmiausia, ar yra koks nors visuomenès nuomonès poslinkis, ịvykęs per pastaruosius penkerius metus. Antra, ar dabartinio (išrinkto 2016 m.) Seimo jausminis 
ir vertinamasis santykis su Lietuva (Seimo kaip visumos nuomonę atspindi politinio elito atsakymai) yra artimas ar tolimas (artimesnis ar tolimesnis) atstovaujamos tautos laikysenai ir jausenai. Per šią Seimo kadenciją atlikus tokią gyventojų apklausą būtų galima analizuoti ir tai, kiek partinès preferencijos veikia didžiavimosi Lietuva ar gèdos dèl Lietuvos jausmus, ir ar tie tikètini partinių simpatijų pagrindu besireiškiantys gyventojų tapatinimosi su Lietuva profiliai sutampa (nesutampa) su jų atstovų Seime susikurtais Lietuvos vaizdiniais.

Ketvirta, būtų ịdomu sužinoti, kaip „išeivijos“ auditorija atsakytų ị šiuos klausimus ir ị ką jos nuomonè būtų panašesnè - i dabartinị politinị elitą ar bendrai ị Lietuvos gyventojus. O gal ši auditorija turi savo atskirą „burbulą“, kurị galbūt dar labiau stiprina tebevykstantys ginčai dèl dvigubos pilietybès ịteisinimo? Derètų labiau pasigilinti ir $\mathfrak{i}$ tai, kad empiriniai duomenys rodo, jog Lietuvos politiniam elitui beveik 100 proc. „geriau būti Lietuvos, o ne kurios kitos šalies piliečiu“, tačiau vos kas antras šalies gyventojas patvirtino Lietuvos pilietybès privalumus ir teigiamą išskirtinumą.

Priedai

1 lentelè. Klausimas: ar jūs didžiuojatès Lietuva dèl...?

\begin{tabular}{|l|c|c|c|c|}
\hline \multicolumn{1}{|c|}{$\begin{array}{c}\text { Ar jūs didžiuojatès Lietuva } \\
\text { dèl... }\end{array}$} & $\begin{array}{c}\text { Labai } \\
\text { didžiuo- } \\
\text { juosi }\end{array}$ & $\begin{array}{c}\text { Šiek tiek } \\
\text { didžiuo- } \\
\text { juosi }\end{array}$ & $\begin{array}{c}\text { Nelabai } \\
\text { didžiuo- } \\
\text { juosi }\end{array}$ & $\begin{array}{c}\text { Visai } \\
\text { nesidi- } \\
\text { džiuoju }\end{array}$ \\
\hline to, kaip joje veikia demokratija & 1 & 2 & 3 & 4 \\
\hline jos politinès įtakos pasaulyje & 1 & 2 & 3 & 4 \\
\hline jos ekonominių pasiekimų & 1 & 2 & 3 & 4 \\
\hline jos socialinės apsaugos sistemos & 1 & 2 & 3 & 4 \\
\hline $\begin{array}{l}\text { jos mokslinių ir technologinių } \\
\text { pasiekimų }\end{array}$ & 1 & 2 & 3 & 4 \\
\hline jos pasiekimų sporte & 1 & 2 & 3 & 4 \\
\hline $\begin{array}{l}\text { jos pasiekimų mene ir litera- } \\
\text { tūroje }\end{array}$ & 1 & 2 & 3 & 4 \\
\hline
\end{tabular}




\begin{tabular}{|l|c|c|c|c|}
\hline \multicolumn{1}{|c|}{$\begin{array}{c}\text { Ar jūs didžiuojatės Lietuva } \\
\text { dèl... }\end{array}$} & $\begin{array}{c}\text { Labai } \\
\text { didžiuo- } \\
\text { juosi }\end{array}$ & $\begin{array}{c}\text { Šiek tiek } \\
\text { didžiuo- } \\
\text { juosi }\end{array}$ & $\begin{array}{c}\text { Nelabai } \\
\text { didžiuo- } \\
\text { juosi }\end{array}$ & $\begin{array}{c}\text { Visai } \\
\text { nesidi- } \\
\text { džiuoju }\end{array}$ \\
\hline jos karinių pajègu & 1 & 2 & 3 & 4 \\
\hline jos istorijos & 1 & 2 & 3 & 4 \\
\hline $\begin{array}{l}\text { to, kad su visomis visuomenès } \\
\text { grupemis joje elgiamasi vieno- } \\
\text { dai ir teisingai }\end{array}$ & 1 & 2 & 3 & 4 \\
\hline
\end{tabular}

2 lentele. Klausimas: pritariate ar nepritariate toliau nurodytiems teiginiams?

\begin{tabular}{|c|c|c|c|c|c|}
\hline $\begin{array}{l}\text { Pritariate ar nepritariate } \\
\text { šiems teiginiams }\end{array}$ & 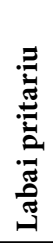 & م & 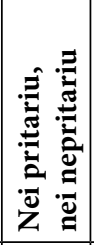 & : & 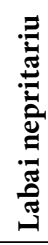 \\
\hline $\begin{array}{l}\text { Man geriau būti Lietuvos piliečiu nei bet } \\
\text { kurios kitos pasaulio šalies piliečiu }\end{array}$ & 1 & 2 & 3 & 4 & 5 \\
\hline $\begin{array}{l}\text { Šiuo metu Lietuvoje yra tam tikrų daly- } \\
\text { kų, dèl kurių man géda }\end{array}$ & 1 & 2 & 3 & 4 & 5 \\
\hline $\begin{array}{l}\text { Pasaulis būtų geresnis, jeigu žmonès iš } \\
\text { kitų šalių būtų panašesni į lietuvius }\end{array}$ & 1 & 2 & 3 & 4 & 5 \\
\hline $\begin{array}{l}\text { Apskritai Lietuva yra geresnè šalis nei } \\
\text { dauguma kitų šalių }\end{array}$ & 1 & 2 & 3 & 4 & 5 \\
\hline $\begin{array}{l}\text { Žmonès turi palaikyti savo šalì, net jei ji } \\
\text { eina neteisingu keliu }\end{array}$ & 1 & 2 & 3 & 4 & 5 \\
\hline $\begin{array}{l}\text { Kai mano šaliai pasiseka tarptautinèse } \\
\text { sporto varžybose, aš didžiuojuosi tuo, } \\
\text { kad esu lietuvis }\end{array}$ & 1 & 2 & 3 & 4 & 5 \\
\hline $\begin{array}{l}\text { Aš dažnai nesididžiuoju Lietuva tiek, } \\
\text { kiek noréčiau }\end{array}$ & 1 & 2 & 3 & 4 & 5 \\
\hline $\begin{array}{l}\text { Pasaulis būtų geresnis, jei lietuviai pripa- } \\
\text { žintų Lietuvos trūkumus }\end{array}$ & 1 & 2 & 3 & 4 & 5 \\
\hline
\end{tabular}


3 lentele. Realizuota Seimo (2017 m. gegužè) narių imtis $(\mathrm{N}=\mathbf{5 6})$ pagal partijas

\begin{tabular}{|l|c|c|c|c|}
\hline \multicolumn{1}{|c|}{ Partijos } & Užpildè & Seime & $\begin{array}{c}\text { Seime } \\
\text { proc. }\end{array}$ & $\begin{array}{c}\text { Užpil- } \\
\text { džiusių } \\
\text { proc. }\end{array}$ \\
\hline $\begin{array}{l}\text { Lietuvos valstiečių ir žaliųjų } \\
\text { sąjunga }\end{array}$ & 21 & 57 & 41 & 37,5 \\
\hline $\begin{array}{l}\text { Tėvynės sąjunga-Lietuvos krikščio- } \\
\text { nys demokratai }\end{array}$ & 14 & 31 & 22 & 25 \\
\hline Lietuvos socialdemokratų partija & 9 & 19 & 14 & 16 \\
\hline Liberalų sąjūdis & 5 & 14 & 10 & 9 \\
\hline $\begin{array}{l}\text { Lietuvos lenkų rinkimų akcija- } \\
\text { Krikščioniškų šeimų sąjunga }\end{array}$ & 1 & 8 & 6 & 2 \\
\hline „Tvarka ir teisingumas“ & 4 & 7 & 5 & 7 \\
\hline Mišri grupé & 2 & 4 & 3 & 3,5 \\
\hline Iš viso & 56 & 140 & 100 & 40 \\
\hline
\end{tabular}

4 lentelè. Realizuota Seimo (2017 m. gegužè) narių imtis $(\mathbf{N}=\mathbf{5 6})$ pagal kadencijų skaičių ir lytị (proc.).

\begin{tabular}{|c|c|c|c|c|}
\hline Pasiskirstymas & $\begin{array}{l}\text { Atsakè } \\
\text { moteru }\end{array}$ & Atsakè vyrų & $\underset{\text { Atsake }}{>1 \text { kadencija }}$ & $\begin{array}{c}\text { Atsake } \\
1 \text { (pirma) } \\
\text { kadencija }\end{array}$ \\
\hline & 14 & 42 & 23 & 33 \\
\hline $\begin{array}{l}\text { Pasiskirstymas } \\
\text { apklausoje }\end{array}$ & 25 & 75 & 41 & 59 \\
\hline $\begin{array}{l}\text { Pasiskirstymas } \\
\text { Seime }\end{array}$ & 21 & 79 & 45 & 55 \\
\hline
\end{tabular}




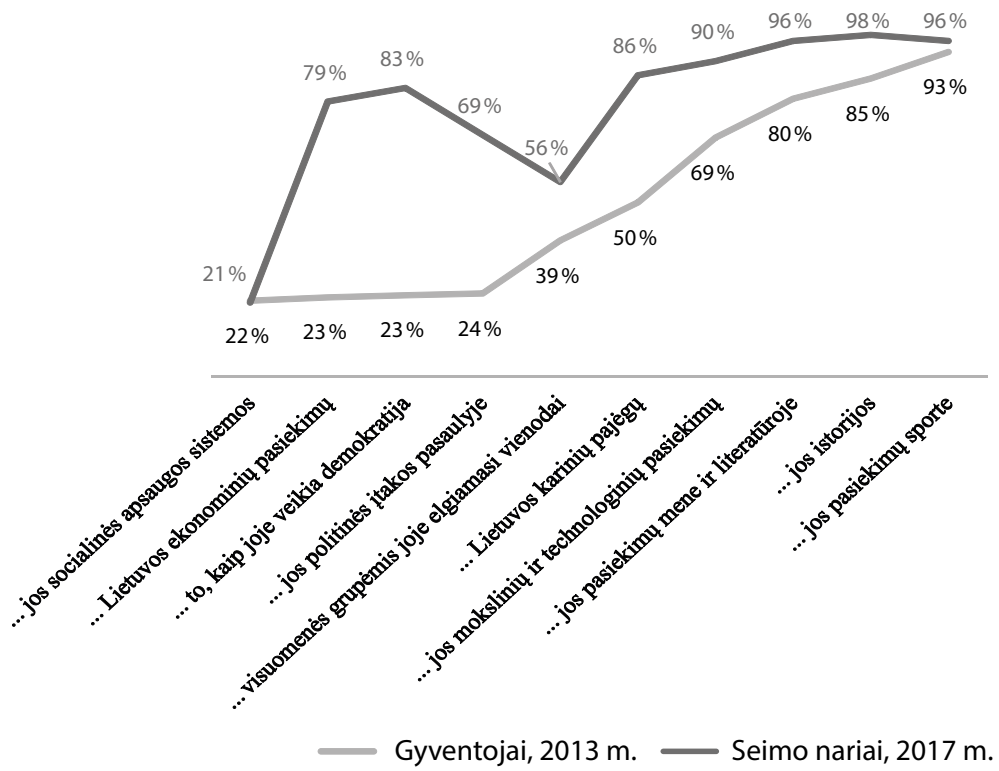

1 diagrama. Kurios sritys labiausiai skatina didžiuotis Lietuva

Ar jūs didžiuojatès Lietuva dèl...? („Visiškai sutinku“ ir „sutinku“ suma. Gyventojai $2013 \mathrm{~m} . \mathrm{N}=1194$, Seimo nariai $2017 \mathrm{~m} . \mathrm{N}=56$ ). 


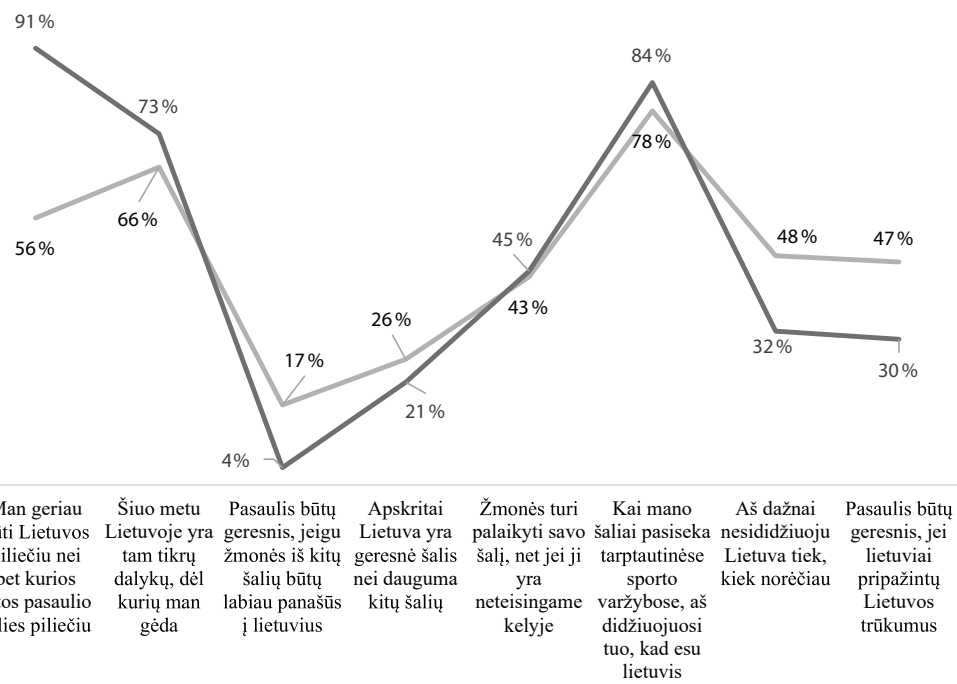

\section{2 diagrama. Motyvai, skatinantys didžiuotis arba gèdytis Lietuva}

Ar pritariate, ar nepritariate šiems teiginiams? („Visiškai pritariu“ ir „pritariu“ suma. Gyventojai 2013 m. N = 1194, Seimo nariai 2017 m. $\mathrm{N}=56$ ). 


\title{
I AM PROUD OF LITHUANIA - A COMPARISON OF ATTITUDES OF THE LITHUANIAN POLITICAL ELITE AND PUBLIC OPINION
}

\author{
IRMINA MATONYTÉ \\ ROBERTA ŠIAUDVYTYTÉ
}

\section{Summary}

Keywords: national identity; state; citizenship; political elite; public opinion.

The affective national identity stems from not necessarily widely understood and explicit, but nevertheless, from more or less clearly recognizable collective values, symbols, patterns of historical memory, evaluation of actions and achievements of the representatives of the country, etc. The identification of citizens with a certain state does not arise "by default", but is constantly revised and collective identity depends on a strong or weak unifying narrative, on quality and direction of certain public policy decisions, on the state of af- fairs and "national" achievements in the international community and in the global arena of sports, culture and arts, etc. The article is based on the analysis of the features of Lithuania as a state and socio-cultural community which are held by public opinion in Lithuania and by Lithuanian political elite as, either, worthy of pride and respect or shameful and disgraceful. The main similarities and differences between attitudes of the Lithuanian political elites and Lithuanian citizens at large are presented and interpreted.

Iteikta 2018 m. rugpjūčio 20 d. 